\title{
Effect of ovine LH on the progesterone content of the granulosa cells in preovulatory follicles of the domestic fowl (Gallus domesticus)
}

\author{
J. Culbert, Marion A. Hardie, J. W. Wells and A. B. Gilbert \\ Agricultural Research Council's Poultry Research Centre, King's Buildings, West Mains Road, \\ Edinburgh EH9 3JS, U.K.
}

\begin{abstract}
Summary. Laying hens were injected i.v. with a single dose of ovine $\mathrm{LH}(100 \mu \mathrm{g})$ 6-8 $\mathrm{h}$ after a known ovulation, i.e. when plasma LH concentrations are low. Groups of 4 birds were killed at $15 \mathrm{~min}$ intervals up to $1 \mathrm{~h}$ after injection and the complete granulosa was obtained from 4 or 5 of the largest preovulatory follicles of each bird for progesterone measurement by g.l.c. Compared with the saline-injected controls which had negligible levels of progesterone, granulosa progesterone increased in all the LH-treated birds. The maximum response (mean progesterone content 1966 $\mathrm{ng} /$ follicle) occurred $45 \mathrm{~min}$ after injection but there was a significant decline by 60 min. It is concluded that the granulosa cells provide most of the preovulatory plasma progesterone increase.
\end{abstract}

\section{Introduction}

The modern light hybrid fowl is almost a daily ovulator. To maintain the output of eggs, the ovary contains a hierarchy of developing follicles measuring $<1$ to $37 \mathrm{~mm}$ in diameter. Concomitant with this follicular growth, the ovary secretes steroid hormones into the blood stream, thus affecting most of the reproductive processes (Gilbert, 1971). Under the influence of gonadotrophins, mainly LH, there is a rise in plasma steroids from about 6 to $2 \mathrm{~h}$ before ovulation (Furr, Bonney, England \& Cunningham, 1973; Shodono, Nakamura, Tanabe \& Wakabayashi, 1975). Shahabi, Norton \& Nalbandov (1975b) and Williams \& Sharp (1978a, b) have emphasized the role of the largest preovulatory follicle in the secretion of the progesterone in this preovulatory phase. However, the ovary contains several types of steroidogenic cells, those of the stroma and those associated with the actual follicle, i.e. the theca and granulosa cells. Our anatomical and analytical studies (Gilbert, Evans, Perry \& Davidson, 1977; Dick, Culbert, Wells, Gilbert \& Davidson, 1978) have shown that the usual practice of slitting the follicle to remove the yolk before analysis would undoubtedly result in the loss of most of the granulosa cells and so the contribution of the granulosa cells to ovarian steroidogenesis in the fowl has probably been underestimated, but the extent of the discrepancy is unknown. Recent studies (Huang, Kao \& Nalbandov, 1979; Wells, Gilbert \& Culbert, 1980) have shown that the granulosa cells in vitro are able to produce progesterone, but there is no evidence for their activity in vivo.

This paper describes the effect of intravenous injection of ovine LH on the progesterone content of the granulosa cells obtained from the larger preovulatory follicles. The work complements that of Shahabi, Bahr \& Nalbandov (1975a) and Imai \& Nalbandov (1978) who measured the progesterone content of the thecal tissue in the follicular envelope after a single injection of $\mathrm{LH}$. 


\section{Materials and Methods}

\section{Animals}

The 21 laying hens (Shaver 288 type) used in these experiments were selected on the basis of egg records and oviposition times from a pool of 60 birds kept as previously described (Gilbert, Davidson \& Wells, 1978). About 6-8 h after a predicted ovulation, each of the 16 experimental birds was weighed and injected intravenously with ovine LH (NIH-LH-S19 $100 \mu \mathrm{g}$ in $300 \mu \mathrm{l}$ $0.15 \mathrm{M}-\mathrm{NaCl}$ ). At $15 \mathrm{~min}$ intervals up to $1 \mathrm{~h}$ after injection, 4 birds at each time were killed by overdose with pentobarbitone sodium, $2 \mathrm{ml}$, i.v. (Expiral: Abbott Laboratories, Kent). All birds had a lightly calcified egg in the shell gland. Four or five of the largest preovulatory follicles were collected from each ovary and weighed. Each follicle was slit, allowing the yolk to fall into $0 \cdot 15$ $\mathbf{M}-\mathrm{NaCl}$. The granulosa cells were separated from the yolk as a unicellular layer contained between the basal lamina and the perivitelline membrane (Gilbert et al., 1977) and this tissue was stored at $-18^{\circ} \mathrm{C}$ until analysed. The predicted time of ovulation of each follicle $(16,40,64,88$ and $112 \mathrm{~h}$ ) was estimated from an examination of the bird's pattern of ovipositing times, together with a comparison of the mass of each follicle and that of the ovum in the calcified egg recovered from the shell gland.

The 5 control birds, selected in a similar way, were injected with $0 \cdot 15 \mathrm{M}-\mathrm{NaCl}(300 \mu \mathrm{l})$ and killed only at $45 \mathrm{~min}$ after injection because Williams \& Sharp (1978a) showed that plasma concentrations of progesterone in saline-injected birds did not change over a 90 min period.

\section{Analysis of tissue}

The granulosa tissue was homogenized with water $(2.5 \mathrm{ml})$ containing $1517 \mathrm{~Bq}[1,2,6,7(\mathrm{n})-$ ${ }^{3} \mathrm{H}$ ]progesterone (sp. act. $3 \cdot 145 \mathrm{kBq} / \mathrm{pmol}$; Radiochemical Centre, Amersham). The homogenate was extracted twice with dichloromethane $(30 \mathrm{ml})$. The combined extract was evaporated down to $1 \mathrm{ml}$ and chromatographed on a column of Florisil $(8 \mathrm{~cm}, 6 \mathrm{~mm}$ diam.; $100-120$ U.S. Mesh). The chromatogram was developed with $25 \mathrm{ml}$ diethyl ether followed by $30 \mathrm{ml}$ ether:methanol $(70: 30 \mathrm{v} / \mathrm{v})$. The latter fraction contained the progesterone and was evaporated to dryness. The residue was dissolved in $25 \mu \mathrm{l}$ acetone from which $5 \mu \mathrm{l}$ were taken for measurement of radioactivity to estimate procedural losses. 5 $\beta$-Pregnane-3,20-dione ( $1 \mu \mathrm{g}$; internal standard) was added to the remaining solution. Portions of this mixture were subjected to gasliquid chromatography (g.l.c.) on OV $210(1.7 \% \mathrm{w} / \mathrm{w})$ coated on Chromsorb G (100-120 U.S. mesh; $1.1 \mathrm{~m} ; 4 \mathrm{~mm}$ ) at $277^{\circ} \mathrm{C}$; using a Pye 104 Chromatograph with argon as the carrier gas and a flame ionization detector. The areas of the separated constituents were measured by a 308 Computing Integrator (L.D.C., Shannon). Progesterone in the sample was estimated from the ratio of its peak area to that of the internal standard. The mass response ratio of progesterone to internal standard was determined with each batch of samples analysed, about 8 each day.

\section{Specificity and sensitivity of the g.l.c. method}

Attempts to perform g.l.c. analyses of crude extracts of granulosa cells were unsuccessful because of gross interference from the cholesterol present. A simple chromatographic step on a Florisil column (Culbert \& Wells, 1973) produced a fraction which was sufficiently purified for g.l.c. Table 1 shows that progesterone was well separated from other naturally occurring steroid hormones or related compounds on OV 210. During these experiments, apart from progesterone and cholesterol, none of the steroids listed in Table 1 was detected in tissue extracts. $5 \beta$ Pregnane-3,20-dione was not separated from its $5 \alpha$-epimer on OV 210 . Occasionally an unidentified peak of retention time $21 \mathrm{~min}$ was observed in extracts but this substance did not interfere with the measurement of progesterone in tissue. The mean \pm s.e.m. recovery of $\left[{ }^{3} \mathrm{H}\right]-$ progesterone from $\mathrm{LH}$ injected birds was $56.7 \pm 1.7 \%$ in 57 analyses; with tissue from saline 
injected birds, the recovery was lower $(34 \pm 3 \cdot 6 \%, n=15)$ because there was a greater loss through lack of carrier steroid.

Table 1. G.l.c. of various steroids on OV 210 at $277^{\circ} \mathrm{C}$

\begin{tabular}{|c|c|}
\hline Steroid & $\begin{array}{l}\text { Retention time } \\
\text { (min) }\end{array}$ \\
\hline Cholesterol & $7 \cdot 5$ \\
\hline Testosterone & 10.7 \\
\hline $20 \beta$-Hydroxypregn-4-ene-3-one & $12 \cdot 5$ \\
\hline $5 \beta$-Pregnane-3,20-dione & 13.4 \\
\hline $20 a$-Hydroxypregn-4-ene-3-one & 13.6 \\
\hline Androstenedione & $15 \cdot 9$ \\
\hline Progesterone & 20.2 \\
\hline
\end{tabular}

The minimum amount of progesterone which was measurable by electronic integration of the peak was $66 \mathrm{ng}$ (coefficient of variation 13\%). This represents about $100 \mathrm{ng}$ in the sample, allowing for losses of about $40 \%$ during the extraction and clean up stages. It was possible to detect, but not measure, 20-50 ng progesterone as a small peak on the baseline. Although not as sensitive as radioimmunoassay, the g.l.c. method is more adaptable for tissue analysis in that a small aliquot of the sample can be tested first. This trial may be used to assess whether dilution or concentration is necessary to bring the progesterone peak within the dynamic range of the detector within $30 \mathrm{~min}$ of the first injection.

\section{Statistical analysis}

During the 60 min after LH injection, the progesterone content of individual granulosa preparations varied considerably between 100 and $6000 \mathrm{ng}$. To normalize the variances for comparison of the means at each sampling time, the individual values were converted to natural logarithms before conducting an analysis of variance. Standard errors of these means (s.e.m.) were calculated from the residual mean squares. Means were compared by Student's $t$ test. The $95 \%$ confidence limits for the geometric means were calculated using their s.e.m. and $t$ values for the appropriate number of degrees of freedom and then converted to the arithmetic scale.

\section{Results}

\section{Granulosa progesterone content after LH injection}

Due to a shortage of ovine LH, dose-response studies were not carried out. However in preliminary studies, 4 birds were injected with $25 \mu \mathrm{g} \mathrm{LH}$ (mean dose $13.7 \pm 0.3 \mu \mathrm{g} / \mathrm{kg}$ body weight). The granulosa tissue of one follicle contained $100 \mathrm{ng}$ progesterone whereas that from the other 15 follicles analysed contained less than the minimum detectable quantity of progesterone, i.e. 20-50 ng. These results were taken to imply that a threshold dose of ovine LH was required to initiate a response by the granulosa cells in vivo $6-8 \mathrm{~h}$ after ovulation when plasma $\mathrm{LH}$ is at a low concentration (Furr et al., 1973; Williams \& Sharp, 1978a). To ensure that a measurable response was attained, an arbitrary amount of $100 \mu \mathrm{g}$ ovine LH was therefore chosen. The mean dose of $\mathrm{LH}$ for the 16 experimental birds used in the current study was $50.8 \mu \mathrm{g} / \mathrm{kg}$, about 2.5 times that used by Williams \& Sharp (1978a).

The fowl ovary contains only one preovulatory follicle at each particular stage of maturity. Since individual birds showed a considerable variation in the granulosa response to the dose of ovine $\mathrm{LH}$, statistical comparisons of the progesterone content in the granulosa of follicles of a particular age were not meaningful because the tissue from 4 birds was examined at each $15-\mathrm{min}$ 
interval. Analysis of variance showed that the major source of variation was between sampling times (with a mean square of 18.0754 (natural logarithms), d.f. $=3$ ) as opposed to that between follicles (with a mean square of 0.7728 , d.f. $=53$ ): the variance ratio $(F)$ was 23.4 and $P<$ 0.001 . The results for the follicles examined in this study are shown in Table 2 .

Table 2. Progesterone content of follicular granulosa collected from the ovaries of laying hens at $15 \mathrm{~min}$ intervals after a single i.v. injection of ovine $\mathrm{LH}(100 \mu \mathrm{g})$

\begin{tabular}{cccc}
\hline & \multicolumn{4}{c}{ Progesterone content (ng/follicle)* } \\
\cline { 2 - 4 } $\begin{array}{c}\text { Time after } \\
\text { injection } \\
\text { (min) }\end{array}$ & $\begin{array}{c}\text { Geometric means } \pm \text { s.e.m. (no. of } \\
\text { follicles) (natural logarithm scale) }\end{array}$ & $\begin{array}{c}\text { Geometric means } \\
\text { (converted to } \\
\text { arithmetic scale) }\end{array}$ & 95\% Confidence limits \\
\hline 15 & ${ }^{a} 6.7259 \pm 0.2651(11)$ & 836 & $463-1510$ \\
30 & $\mathbf{a} 6.6723 \pm 0.2349(14)$ & 790 & $475-1313$ \\
45 & $\mathbf{b} 7.5838 \pm 0.2198(16)$ & 1966 & $1231-3141$ \\
60 & c5.0324 $\pm 0.2198(16)$ & 153 & $96-245$ \\
\hline
\end{tabular}

Means with different superscripts are significantly different $(P<0.05)$.

* The tissues from 4 birds were analysed for each time. The follicles ranged in maturity from 16 to $112 \mathrm{~h}$ before their estimated ovulation.

Granulosa obtained from the 4 or 5 largest follicles dissected from ovaries $12 \mathrm{~h}$ after the preovulatory LH surge in birds injected with saline contained negligible amounts of progesterone, but within $15 \mathrm{~min}$ of an $\mathrm{LH}$ injection into the blood stream, there was at least a 5 -fold rise in the granulosa progesterone levels, increasing during the next $30 \mathrm{~min}$ to over $2000 \mathrm{ng} /$ follicle.

The granulosa tissue from follicles of the control birds contained only negligible levels of progesterone. Only one follicle in 15 examined had a progesterone content (169 $\mathrm{ng}$ ) greater than the detectable limit.

The difference in mass between the four largest follicles of the LH-treated birds was approximately $3 \mathrm{~g} /$ day, e.g. for $16 \mathrm{~h}$ versus $40 \mathrm{~h}$ follicles from the same bird, the mean ( \pm s.e.m.) difference was $2.62 \pm 0.34 \mathrm{~g}(n=13$; paired $t$ test $P<0.001)$, for $40 \mathrm{~h}$ versus $64 \mathrm{~h}, 3.15 \pm 0.32$ $\mathrm{g}(n=8 ; P<0.001)$ and for $64 \mathrm{~h}$ versus $88 \mathrm{~h}$ follicles, $3.20 \pm 0.39 \mathrm{~g}(n=9 ; P<0.001)$.

\section{Discussion}

The impetus to carry out these studies on the effect of LH on granulosa cells in vivo came from related work on the secretion of progesterone by fowl granulosa cells in vitro (Huang et al., 1979; Wells et al., 1980). Cells collected from follicles estimated to be ovulating 1-5, 24 and $48 \mathrm{~h}$ later responded similarly to exogenous ovine $\mathrm{LH}$ with increased secretion of progesterone. Ovine LH elevated progesterone concentration in blood plasma of the fowl for a period of at least $90 \mathrm{~min}$ after the injection (Shahabi et al., 1975a; Williams \& Sharp, 1978a; Imai \& Nalbandov, 1978). Williams \& Sharp (1978a) demonstrated that the response occurred irrespective of whether a bird was in the middle of an egg sequence or on a pause day. Previous studies of the follicular response to LH showed that the theca of the largest follicle contained 200-300 ng progesterone (300-400 ng/g) 30-45 min after treatment (Shahabi et al., 1975a; Imai \& Nalbandov, 1978). Since the tissues studied by these authors would not have contained many granulosa cells (see 'Introduction'), it is not surprising that the present results gave markedly higher values (>2000 ng progesterone/follicle).

We suggest that the granulosa cells of the large preovulatory follicles are the ovarian source of the preovulatory surge of progesterone during the ovulatory cycle of the hen (Wells $e t$ al., 1979). Although the granulosa content at any time does not reflect the actual rate of progester- 
one secretion, the sharp drop in granulosa progesterone levels between 45 and 60 min after LH injection in our study was surprising. There was a net fall of $1812 \mathrm{ng}$ (mean) in the granulosa of each follicle, representing a decrease of $384 \mathrm{pmol} / \mathrm{min}$. Possibly the slower decay in the plasma progesterone concentration observed by Shahabi et al. (1975a) and Williams \& Sharp (1978a) after an LH pulse may be a consequence of the buffering effect of other tissue pools on the metabolic clearance.

Besides confirming the steroidogenic activity of $\mathrm{LH}$ previously demonstrated in vitro (Wells et al., 1980), the similarity of the response of the 4 largest preovulatory follicles to exogenous $\mathrm{LH}$ casts doubt on the assumption that the potential of a follicle to ovulate is determined mainly by its ability to secrete progesterone in the presence of increased concentrations of LH (Etches \& Cunningham, 1976; see also Williams \& Sharp, 1978b) since if this were so, all the larger follicles should ovulate synchronously. On the other hand, after injecting birds with LH, Shahabi et al. (1975a) and Imai \& Nalbandov (1978) showed that the largest follicle had lower oestrogen concentration than the next two follicles in the ovarian hierarchy. A similar pattern of increasing oestrogen concentration with decreasing follicle size was observed during the preovulatory phase of the daily cycle of the hen (Shahabi et al., 1975b). Perhaps a decline in the aromatizing activity of the theca of the largest follicle, coupled with an increasing progesterone secretion by its granulosa in response to $\mathrm{LH}$, is the primary factor in determining whether the hen follicle is ready to ovulate.

We thank Mrs C. C. McCorquadale for statistical advice. We are indebted to N.I.A.M.D., National Institutes of Health, Bethesda, U.S.A., for a generous gift of ovine LH.

\section{References}

Culbert, J. \& Wells, J.W. (1973) Aspects of adrenal function in the domestic fowl. $J$. Endocr. 65, 363376.

Dick, H.R., Culbert, J., Wells, J.W., Gilbert, A.B. \& Davidson, M.F. (1978) Steroid hormones in the postovulatory follicle of the domestic fowl (Gallus domesticus). J. Reprod. Fert. 53, 103-107.

Etches, R.J. \& Cunningham, F.J. (1976) The interrelationship between progesterone and luteinizing hormone during the ovulation cycle of the hen (Gallus domesticus). J. Endocr. 77, 51-58.

Furr, B.J.A., Bonney, R.G., England, R.J. \& Cunningham, F.J. (1973) Luteinizing hormone and progesterone in peripheral blood during the ovulatory cycle of the hen (Gallus domesticus). J. Endocr. 57, 159-169.

Gilbert, A.B. (1971) The endocrine ovary in reproduction. In The Physiology and Biochemistry of the Domestic Fowl, vol. 3, pp. 1149-1168. Eds D. J. Bell \& B. M. Freeman. Academic Press, London.

Gilbert, A.B., Evans, A.J., Perry, M.M. \& Davidson, M.F. (1977) A method for separating the granulosa cells, the basal lamina and the theca of the preovulatory ovarian follicle of the domestic fowl (Gallus domesticus). J. Reprod. Fert. 50, 179-181.

Gilbert, A.B., Davidson, M.F. \& Wells, J.W. (1978) Role of the granulosa cells of the postovulatory follicle of the domestic fowl in oviposition. J. Reprod. Fert. 52, 227-229.

Huang, E. S-R., Kao, K.J. \& Nalbandov, A.V. (1979)
Synthesis of sex steroids by cellular components of chicken follicles. Biol. Reprod. 20, 454-461.

Imai, K. \& Nalbandov, A.V. (1978) Plasma and follicular steroid levels of laying hens after the administration of gonadotrophins. Biol. Reprod. 19, 779-784.

Shahabi, N.A., Bahr, J.M. \& Nalbandov, A.V. (1975a) Effect of LH injection on plasma and follicular steroids in the chicken. Endocrinology 96, 969-972.

Shahabi, N.A., Norton, H.W. \& Nalbandov, A.V. (1975b) Steroid levels in follicles and the plasma of hens during the ovulatory cycle. Endocrinology 96, 962-968.

Shodono, M., Nakamura, T., Tanabe, Y. \& Wakabayashi, K. (1975). Simultaneous determinations of oestradiol-17 $\beta$, progesterone and luteinizing hormone in the plasma during the ovulatory cycle of the hen. Acta endocr., Copenh. 78, 565-573.

Wells, J.W., Gilbert, A.B. \& Culbert, J. (1980) The effect of luteinizing hormone on progesterone secretion in vitro by the granulosa cells of the domestic fowl (Gallus domesticus). J. Endocr. (in press).

Williams, J.B. \& Sharp, P.J. (1978a) Age-dependent changes in the hypothalamo-pituitary-ovarian axis of the laying hen. J. Reprod. Fert. 53, 141-146.

Williams, J.B. \& Sharp, P.J. (1978b) Control of the preovulatory surge of luteinizing hormone in the hen (Gallus domesticus): the role of progesterone and androgens. $J$. Endocr. 77, 57-65. 